\title{
The Application of Filter Cake Compost to Improve The Efficiency of Inorganic Fertilizer in Upland Sugarcane (Saccharum officinarum L.) Cultivation
}

DOI: $10.18196 /$ pt.2020.119.93-102

\author{
Dharend Lingga Wibisana ${ }^{1^{*}}$, Purwono ${ }^{2}$, Sudirman Yahya ${ }^{2}$ \\ ${ }^{1}$ Study Program of Agronomy and Horticulture, Graduate School, IPB University, \\ Jl Meranti, Kampus IPB Dramaga, Bogor 16680, Indonesia \\ ${ }^{2}$ Department of Agronomy and Horticulture, Faculty of Agriculture, IPB University, \\ Jl Meranti, Kampus IPB Dramaga, Bogor 16680, Indonesia \\ *Corresponding author, email: dharendlingga@gmail.com/dharend_lingga@apps.ipb.ac.id
}

\begin{abstract}
The production of sugarcane in 2018 decreased due to the change in the cultivation method from lowland to upland. This research aimed to study the responses of growth and yield of two sugarcane varieties to the application of filter cake compost and inorganic fertilizer in upland sugarcane cultivation. This experiment was arranged in a split-split plot design consisting of three-factors, which were sugarcane varieties, the levels of filter cake compost, and the rates of inorganic fertilizer, assigned to the main plot, sub-plot, and sub-sub plots, respectively. The two sugarcane varieties were PS 881 and PS 862. The three levels of filter cake compost were 0, 5, 10 tons ha-1, and the four rates of inorganic fertilizers (percent of recommended dosage) were 25\%, 50\%, 75\%, and 100\%. The results showed that the growth and yield of PS 862 was better than that of PS 881 , shown in the plant height, stem diameter, number of stems, and the length of internodes. The use of filter cake compost at a dose of 5 tons ha-1 was more efficient, and it could provide an efficiency of 0.097 tons per $\mathrm{kg}$ of cane at a dose of $76.76 \%$ inorganic fertilizer. Yet, it cannot reduce the use of inorganic fertilizer in producing sugarcane yield.

Keywords: Compost, Efficiency, Internode, PS 881, Yield
\end{abstract}

\section{ABSTRAK}

Produksi tebu pada tahun 2018 menurun dikarenakan pertanaman tebu berubah dari lahan sawah menjadi lahan kering. Penelitian ini bertujuan untuk mempelajari respon pertumbuhan dan hasil dua varietas dengan aplikasi kompos blotong dan pupuk anorganik pada pertanaman tebu lahan kering. Penelitian ini telah dilaksanakan di PT Kebun Tebu Mas, Mantup, Lamongan, Jawa Timur. Percobaan disusun dengan rancangan petak-petak terpisah (split-split plot design). Perlakuan yang digunakan terdiri dari tiga faktor yaitu varietas, tiga taraf kompos blotong dan empat dosis pupuk anorganik yang tersusun berturutturut sebagai petak utama, anak petak dan anak-anak petak. Varietas yang digunakan adalah PS 881 dan PS 862, pupuk kompos blotong terdiri dari tiga taraf yaitu 0, 5 dan 10 ton per hektar dan empat dosis pupuk anorganik (persen dosis rekomendasi) yaitu 25\%, 50\%, 75\% dan 100\%. Hasil menunjukkan bahwa pertumbuhan dan hasil varietas PS 862 lebih baik daripada PS 881 pada keragaan tinggi tanaman, diameter batang, jumah batang dan panjang ruas. Dosis kompos blotong 5 ton ha-1 merupakan dosis terbaik dan dapat meningkatkan efisiensi pupuk anorganik sebesar 0,097 ton $\mathrm{kg}^{-1}$ pada dosis $76.76 \%$. Hal tersebut belum mampu mereduksi penggunaan pupuk anorganik dalam menghasilkan tonase tebu.

Kata Kunci: Efisiensi, Hasil, Kompos, PS 881, Ruas

\section{INTRODUCTION}

National sugar demand per year is 5.7 million tons in the form of 3.2 million tons refined crystal sugar for industry and 2.5 million tons of white crystal sugar for consumption. National sugarcane production in 2018 was 2.17 million tons lower than in 2016, which was 2.2 million tons (Directorate General of Plantations, 2019). Such problem has occured due to the change in sugarcane cultivation in Indonesia from lowland to suboptimal lands, such as upland. Indonesia has an upland area of 144.5 million hectares consisting of 37.1 million hectares of nonacidic upland, 107.3 million hectares of acid upland, and 10.7 million hectares of dry climate, which are all scattered in various regions (Abdurachman et al., 2008; Indonesian Center for Agricultural Land Resources, 2015).

Upland has a deficiency of cation exchange capacity (CEC) and low organic C content, and total evaporation from the soil is not balanced by the amount of rainfall so that the availability of water and soil nutrients is limited (Budiyanto, 2014; Rahayu et al., 2014). According to the Soil 
Research Institute, the organic $\mathrm{C}$ content in good soil is at a moderate level of 2-3\% (Soil Research Institute, 2009). The limited environmental conditions lead to various activities of sugarcane, such as morphological, physiological, and gene expression responses throught the mechanism of tolerance and avoidance (Jain et al., 2015; Ferreira et al., 2017; Zhao et al., 2017). The plant response to avoid drought stress is water loss at leaf transpiration, stomatal closure, and low leaf chlorophyll concentration, reducing the availability of $\mathrm{CO}_{2}$ and then inhibiting biomass production (Silveira et al., 2016). Mastur (2016) explains that a decrease in the rate of photosynthesis and the availability of water and soil nutrients can reduce the rate of plant growth and sugar production. Under these conditions, the efforts must be made to add inorganic fertilizers promptly and to use superior sugarcane varieties.

The recommended dose for sugarcane fertilization is $100-120 \mathrm{~kg} \mathrm{ha}^{-1} \mathrm{~N}, 100-200 \mathrm{~kg} \mathrm{ha}^{-1} \mathrm{P}$, and $100-200 \mathrm{~kg} \mathrm{ha}^{-1} \mathrm{~K}$ to produce 100 ton ha ${ }^{-1}$ of sugarcane (Santos et al., 2015). Sugarcane productivity increased by $5.82 \%$ as affected by compound fertilizer packages with $\mathrm{Ca}$ and $\mathrm{Mg}$ without manure (Supriyadi, Diana, \& Djumali, 2018). However, those recommendations are not able to improve the quality of soil in the upland so that additional handling is required. Improving soil quality by adding organic matter is one of the methods in scaling production in plant cultivation. The addition of organic fertilizer was applied to the soil to improve the holding capacity of water, cation exchange capacity, soil structure, nutrient availability, and nutrient storage in the soil (Bot and Benites, 2005). Organic matter is easily made and obtained from sugarcane milling waste as a filter cake. Filter cake is a waste originating from the sap in the process of grinding sugarcane, and not enough research has been done on sugarcane cultivation in Indonesia. The applica- tion of 3-5 tons filter cake compost under drought stress conditions can reduce watering time intervals to fulfill the water needs of sugar cane plants and increase water holding capacity in the soil, thereby increasing the yield (Purwono, Sopandie, Harjadi, \& Mulyanto, 2011). Reducing inorganic fertilizers in sugarcane and corn cultivation increased the productivity of the plants (Usman et al., 2015; Dotaniya et al., 2016; Jaili and Purwono, 2016). The application of organic fertilizer as mill ash resulted in the highest cation exchange capacity and nutrient concentrations, and these properties could increase nutrient availability in sandy soil in the short and long term contributing to the growth of biomass and sugarcane sucrose yield (Gomez 2013; Shukla et al., 2015; Alvarez-Campos et al., 2018). The analysis of the filter cake compost showed that it contained $0.89 \% \mathrm{~N}, 0.17 \% \mathrm{P}$, and $0.70 \% \mathrm{~K}$ and $17.46 \%$ organic $\mathrm{C}$, which are expected to help improve soil quality and improve sugarcane production. This research aimed to study the responses of growth and yield of two sugarcane varieties to the application of filter cake compos, as well as to determine the efficiency of inorganic fertilizer in upland sugarcane cultivation.

\section{MATERIALS AND METHOD}

This research was conducted in the sugarcane field with Vertisol soil type and clay soil texture at 90 meters above sea level from October 2018 to July 2019. This study was arranged in a separated split-split plot design with three factors, namely sugarcane $(\mathrm{V})$ varieties, levels of filter cake compost $(\mathrm{K})$, and doses of inorganic fertilizer $(\mathrm{A})$ as the main plot, sub-plot, and sub-sub plots, repectively. The two sugarcane varieties were PS 881 (V1) and PS 862 (V2). The filter cake compost consisted of three levels, which were 0 (K1), 5 (K2), and 10 ton $\mathrm{ha}^{-1}(\mathrm{~K} 3)$, and the treatment of inorganic fertilizers consisted of four doses (percent of recommenda- 
tion), which were 25\% (45 kg Z.A. and $30 \mathrm{~kg} \mathrm{NPK)}$ (A1), 50\% (90 kg Z.A. and $60 \mathrm{~kg} \mathrm{NPK)} \mathrm{(A2),} \mathrm{75 \%}$ (135 kg Z.A. and $90 \mathrm{~kg}$ NPK) (A3) and 100\% (180 $\mathrm{kg}$ Z.A. and 120 NPK) (A4). Each treatment combination was repliated three times. The additive linear model used in this design is:

$$
\begin{aligned}
\mathrm{Yijkl}= & \mu+\rho \mathrm{i}+\alpha \mathrm{j}+\delta \mathrm{ij}+\beta \mathrm{k}+(\alpha \beta) \mathrm{jk}+\delta \mathrm{ijk}+\gamma \mathrm{i} \\
& +(\alpha \gamma) \mathrm{jl}+(\beta \gamma) \mathrm{kl}+(\alpha \beta \gamma) \mathrm{jkl}+\delta \mathrm{ijkl}
\end{aligned}
$$

The experiment was carried out in the upland, and the land preparation used was Juringan or furrow system with a length of $6 \mathrm{~m}$, and each furrow was separated by a range of $0.5 \mathrm{~m}$. The distance between furrow centers is $1.1 \mathrm{~m}$, with a width of $0.45 \mathrm{~m}$ and the ridge of $0.65 \mathrm{~m}$. Each trial unit consiststed of 5 furrows so that the total furrows required were $5 \times 72=360$ furrows. The land area required was around $3000 \mathrm{~m}^{2}$.

Planting was carried out using single bud planting seedlings that had been in a nursery for 2.5 months from the plantation of P.T. Kebun Tebu Mas. The plant spacing was $0.5 \mathrm{~m}$ with one single bud in each planting hole so that each furrow had 11 single buds. The bud replacement was done one week after planting using the same single bud seeds (seedlings that were grown together when planting). Fertilizing was done according to the recommended doses from P.T. Kebun Tebu Mas, which were $600 \mathrm{~kg} \mathrm{ha}^{-1}$ Z.A. plus $400 \mathrm{~kg} \mathrm{ha}^{-1} \mathrm{NPK}$ equivalent to $186 \mathrm{~kg} \mathrm{~N}$ ha $^{-1}, 60 \mathrm{~kg} \mathrm{ha}^{-1} \mathrm{P}_{2} \mathrm{O}_{5}, 60 \mathrm{~kg}$ $\mathrm{ha}^{-1} \mathrm{~K}_{2} \mathrm{O}$ and $144 \mathrm{~kg} \mathrm{ha}^{-1}$ S. Z.A. The NPK fertilizers were applied three times, namely as the basic fertilization, as supplementary fertilization at four weeks after planting (WAP), and at eight WAP. Fertilization was carried out using placement techniques following the needs of each variety $(0.5 \mathrm{~kg}$ Z.A. and $0.33 \mathrm{NPK}$ for three times fertilization). Filter cake compost was given one week before planting according to the treatment doses by sowing the compost evenly in the planting hole in each furrow.

The analysis of soil and filter cake compost was carried out in the Laboratory of Soil and Plant, IPB University. The data of the vegetative growth were recorded on six sample plants per plot taken from the $2 \mathrm{nd}, 3 \mathrm{rd}$, and 4 th furrow. The observations were started when the plants were one month after planting (MAP). The agronomic chracters observed included plant height, number of leaves, leaf area, number of tillers, number and length of stems, nunber and range of internodes, and stem diameter. Meanwhile, the physiological charcters observed included leaf pigment content (chlorophyll a and b) and leaf nutrient analysis (on leaves +1 ). The yield component was observed by taking data of stem length, number of stems per meter, and stem weight. They were used to estimate the efficiency of inorganic fertilizer

$$
\text { (formula: } \overline{\text { amount of inorganic fertilizer }} \text { ) and sug- }
$$
arcane yield in ton per hectare. The data obtained were analyzed with analysis of variance at $5 \%$, followed by Duncan multiple range tests (DMRT) to determine the effect of filter cake compost and polynomial orthogonal tests to determine differences in responses to the inorganic fertilizer doses.

\section{RESULTS AND DISCUSSION}

The strategy to increase sugarcane productivity expected from this research is the improvement of soil quality through the efficiency of inorganic fertilizer and the application of filter cake compost to achieve an increase in the sugarcane yield. Therefore, the application of organic matter in the form of filter cake compost combined with reduced doses of inorganic fertilizer is expected to increase the number of tillers and the stem diameter in the sugarcane cultivation.

Climate condition in the experimental site is described in Figure 1. There was no rain in Octo- 


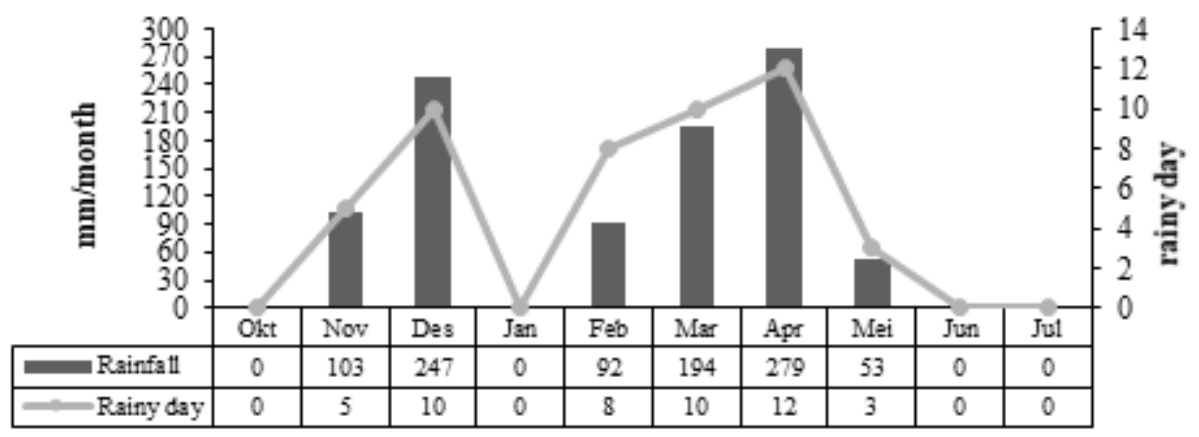

Figure 1. Rainfall data in Mantup District from October 2018 to July 2019

ber 2018, so manual watering was carried out to meet the water requirement for the crops. Rainfall began in November 2018 and lasted to December 2018 with low rainy days. Water deficit conditions cause plant growth to be disrupted, resulting in the inhibition of cell enlargement and extension (Arve et al., 2011; Widiyani and Ariffin, 2017).

The soil analysis before the experiment showed that the soil texture at the experimental site was clay with Vertisol soil type (Table 1). The content of organic matter and nitrogen is very low, the $\mathrm{pH}$ is slightly acidic, and the nutrient content of $\mathrm{P}$ and $\mathrm{K}$ is low, whereas $\mathrm{Ca}$ nutrient is very high (Soil Research Institute, 2009). The explanation shows that the condition of the land used is suboptimal land, which has low nutrient content and low organic matter.
The results of the filter cake compost analysis showed that the water holding capacity was $35.50 \%$ (Table 2). Besides, the organic $\mathrm{C}$ content of $17.46 \%$ (Gravimetric method), which was higher than the organic $\mathrm{C}$ content in the soil will help improve the quality of the physical properties of the soil. The $\mathrm{C} / \mathrm{N}$ ratio of the filter cake compost ratio (19.61) indicated that compost was still undergoing a decomposition process, inhibiting the nutrient availability in the soil. Mature compost standards show a C/N ratio of 8-15 (Soil Research Institute, 2009).

Effects of filter cake compost and inorganic fertilizer on sugarcane growth

The plant height of bith sugarcane varieties increased, which tended to be the same from the age of 4 WAP to 25 WAP (Figure 2). The growth

Table 1. Chemical-physical properties of Vertisol

\begin{tabular}{|c|c|c|c|c|}
\hline Soil Properties & Methods & Unit & Value & Criteria \\
\hline pH & $\mathrm{H}_{2} \mathrm{O}$ & & 6.45 & Rather acidic \\
\hline C-Organik & Walkey \& Black & $\%$ & 0.63 & Very low \\
\hline $\mathrm{N}$ total & Khejdahl & $\%$ & 0.08 & Very low \\
\hline $\mathrm{C} / \mathrm{N}$ ratio & & & 7.87 & Low \\
\hline $\mathrm{P}_{2} \mathrm{O}_{5}$ & Bray & $\mathrm{ppm}$ & 10.68 & Moderate \\
\hline K & $\mathrm{N} \mathrm{NH}_{4} \mathrm{Oac} \mathrm{pH} 7$ & $\mathrm{cmol}(+) / \mathrm{kg}$ & 0.28 & Low \\
\hline $\mathrm{Ca}$ & $\mathrm{N} \mathrm{NH}_{4} \mathrm{Oac} \mathrm{pH} 7$ & $\mathrm{cmol}(+) / \mathrm{kg}$ & 42.87 & Very high \\
\hline $\mathrm{Mg}$ & $\mathrm{N} \mathrm{NH}_{4} \mathrm{Oac} \mathrm{pH} 7$ & $\mathrm{cmol}(+) / \mathrm{kg}$ & 5.61 & High \\
\hline $\mathrm{Na}$ & $\mathrm{N} \mathrm{NH}_{4} \mathrm{Oac} \mathrm{pH} 7$ & $\mathrm{cmol}(+) / \mathrm{kg}$ & 0.21 & Low \\
\hline KTK & $\mathrm{N} \mathrm{NH}_{4} \mathrm{Oac} \mathrm{pH} 7$ & $\mathrm{cmol}(+) / \mathrm{kg}$ & 6.76 & Low \\
\hline Texture & Pipette method & & & \\
\hline Sand & & $\%$ & 8.00 & \\
\hline Silt & & $\%$ & 23.17 & Clay \\
\hline Clay & & $\%$ & 68.83 & \\
\hline
\end{tabular}


Table 2. Results of filter cake compost analysis

\begin{tabular}{lccc}
\hline Component of analysis & Methods & Unit & Analysis result \\
\hline $\mathrm{pH}$ & $\mathrm{H}_{2} \mathrm{O}$ & $\%$ & 7.20 \\
Organic $\mathrm{C}$ & Gravimetric & $\%$ & 17.46 \\
$\mathrm{~N}$ total & Khejdahl & & 0.89 \\
$\mathrm{C} / \mathrm{N}$ ratio & & $\%$ & 19.61 \\
$\mathrm{P}_{2} \mathrm{O}_{5}$ & Wet ashing & $\%$ & 0.17 \\
$\mathrm{~K}_{2} \mathrm{O}$ & Wet ashing & $\%$ & 0.70 \\
$\mathrm{Ca}$ & Wet ashing & $\%$ & 12.20 \\
$\mathrm{Mg}$ & Wet ashing & $\%$ & 0.34 \\
Water content & Gravimetric & & 35.50 \\
\hline
\end{tabular}

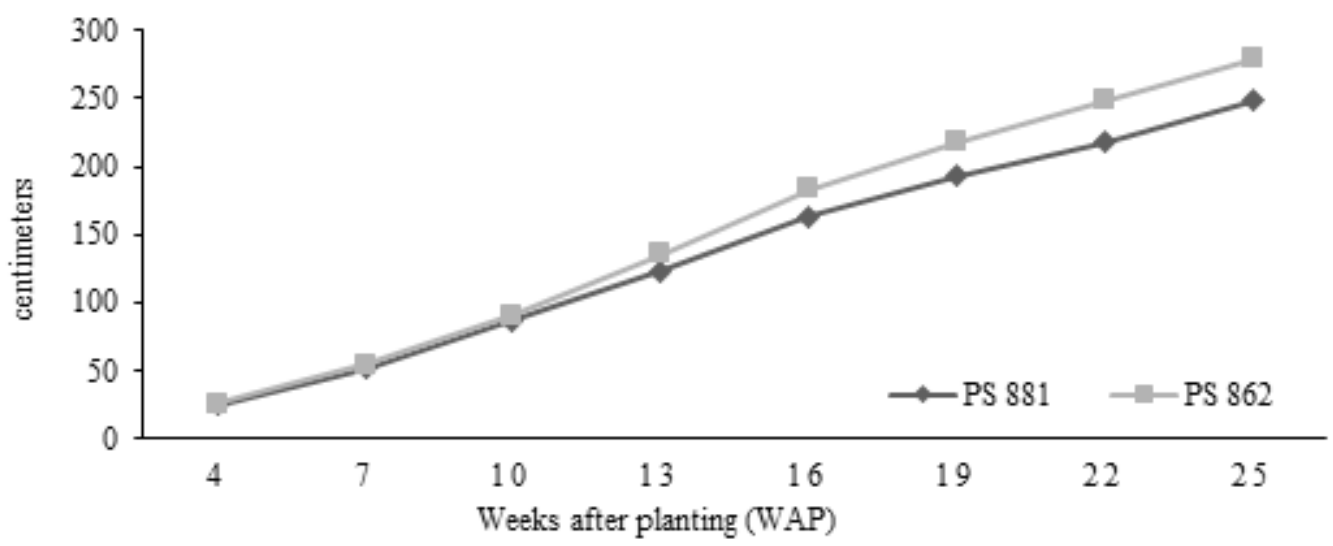

figure 2. Curve of sugarcane plant height

performance of both varieties has similar morphological characteristics, such as early and middle early maturity types. The analysis result (Table 3) showed that the number of stems was not affected by variety, but the application of filter cake compost significantly affected the leaf area. Meanwhile, the doses of inorganic fertilizer applied significantly affected the number of tillers and stem considerably.

Filter cake compost and inorganic fertilizer treatment did not significantly affect the number of leaves (Table 3). This is opposite to the explanation of Silva et al. (2019), mentioning that the higher dose of $\mathrm{N}$ from various fertilizer sources increases the number of leaves in sugarcane. Meanwhile, the application of filter cake compost significantly affected the leaf area at 25 WAP (Table 3) due to the delay in the availability of nutrients in the soil caused by filter cake compost, which is still undergoing a decomposition process.
The application of inorganic fertilizers at doses higher than 50\% no longer increased the number of tillers and stems (Table 3). Diana et al. (2016) reported that the application of inorganic fertilizers at different doses affected the number of stems during sugarcane growth.

Interaction betwen sugarcane variety and filter cake compost (Table 4) shows that both varieties are responsive to the internodes formation. PS 881 variety is more responsive in the length of the internodes at 22 and 25 WAP compared to PS 862 variety. The result showed that the length of the internodes of both sugarcane varieties (PS 881 and PS 862) was more determined by genetic traits rather than by fertilizer treatment. However, the application of filter cake compost affected the availability of nutrients and water in the soil so that the nutrient uptake process by plant roots was not hampered. The application of organic matter 
Table 3. Average of the growth variable at 25 WAP

\begin{tabular}{|c|c|c|c|c|}
\hline Treatment & Number of leaves & Number of tillers & Number of stems & Leaf area \\
\hline \multicolumn{5}{|l|}{ Varieties } \\
\hline PS 881 & $19.69 \mathrm{~b}$ & $6.29 b$ & 6.09 & $428.67 \mathrm{~b}$ \\
\hline PS 862 & $21.14 \mathrm{a}$ & $7.06 a$ & 6.64 & $508.75 \mathrm{a}$ \\
\hline \multicolumn{5}{|c|}{ Filter cake compost } \\
\hline 0 ton $\mathrm{ha}^{-1}$ & 20.37 & 6.47 & 6.16 & $451.78 b$ \\
\hline 5 tons ha-1 & 20.50 & 6.66 & 6.35 & $468.80 \mathrm{~b}$ \\
\hline 10 tons ha $^{-1}$ & 20.38 & 6.90 & 6.59 & $485.56 \mathrm{a}$ \\
\hline \multicolumn{5}{|c|}{ Inorganic fertilizer } \\
\hline $25 \%$ & 20.04 & $5.62 b$ & $5.11 \mathrm{~b}$ & 449.35 \\
\hline $50 \%$ & 20.39 & $6.93 a$ & $6.80 \mathrm{a}$ & 484.18 \\
\hline $75 \%$ & 20.46 & $7.05 \mathrm{a}$ & $6.75 \mathrm{a}$ & 469.96 \\
\hline $100 \%$ & 20.77 & $7.12 \mathrm{a}$ & $6.81 \mathrm{a}$ & 471.36 \\
\hline
\end{tabular}

Note: Values followed by the same letters within a column are not significantly different at $5 \%$. WAP= weeks after planting

Table 4. Interactions of sugarcane variety and filter cake compost on the number and length of internodes

\begin{tabular}{lcccccc}
\hline \multirow{2}{*}{ Filter cake compost } & \multicolumn{2}{c}{ N.I. 22 WAP } & \multicolumn{2}{c}{ LI 22 WAP } & \multicolumn{2}{c}{ LI 25 WAP } \\
\cline { 2 - 6 } & PS 881 & PS 862 & PS 881 & PS 862 & PS 881 & PS 862 \\
\hline 0 ton ha $^{-1}$ & $14.03 \mathrm{cx}$ & $14.06 \mathrm{cx}$ & $10.13 \mathrm{cy}$ & $12.08 \mathrm{ax}$ & $9.85 \mathrm{~d} \mathrm{y}$ & $11.97 \mathrm{ax}$ \\
5 ton ha $^{-1}$ & $14.61 \mathrm{bx}$ & $14.65 \mathrm{bx}$ & $10.35 \mathrm{cy}$ & $11.23 \mathrm{bx}$ & $10.27 \mathrm{cy}$ & $11.00 \mathrm{bx}$ \\
10 ton ha $^{-1}$ & $15.24 \mathrm{ax}$ & $14.15 \mathrm{cy}$ & $9.28 \mathrm{~d} \mathrm{y}$ & $12.25 \mathrm{ax}$ & $9.55 \mathrm{e} \mathrm{y}$ & $12.22 \mathrm{ax}$ \\
\hline
\end{tabular}

Note: Values followed by the same letters within a column are not significantly different at $5 \%$. N.I.: number of internodes; LI: length of internodes; WAP: weeks after planting.

could improve soil quality, following Ghube et al. (2017) and Banerjee et al. (2018) that the addition of manure, inorganic fertilizer, and microorganisms could improve the level of water infiltration into the soil better compared to without treatment.

The interaction effect of filter cake compost and inorganic fertilizer on the stem diameter of PS 881 variety at 22 WAP is presented on Table 5 and Figure 3a. The application of 0 tons ha ${ }^{-1}$ filter cake compost is illustrated by a quadratic equation ( $\mathrm{y}=$ $\left.-0.0008 x^{2}+0.1215 x+22.655\right)$ with an optimum inorganic fertilizer dose of $75.93 \%$. The use of filter cake compost improved inorganic fertilizer efficiency at the treatment of 100\% inorganic fertilizer dose in the stem diameter formation of PS 881. The requirements of nutrients and water in the soil for the plant stem cell divisons were sufficiently fulfilled by filter cake compost application.
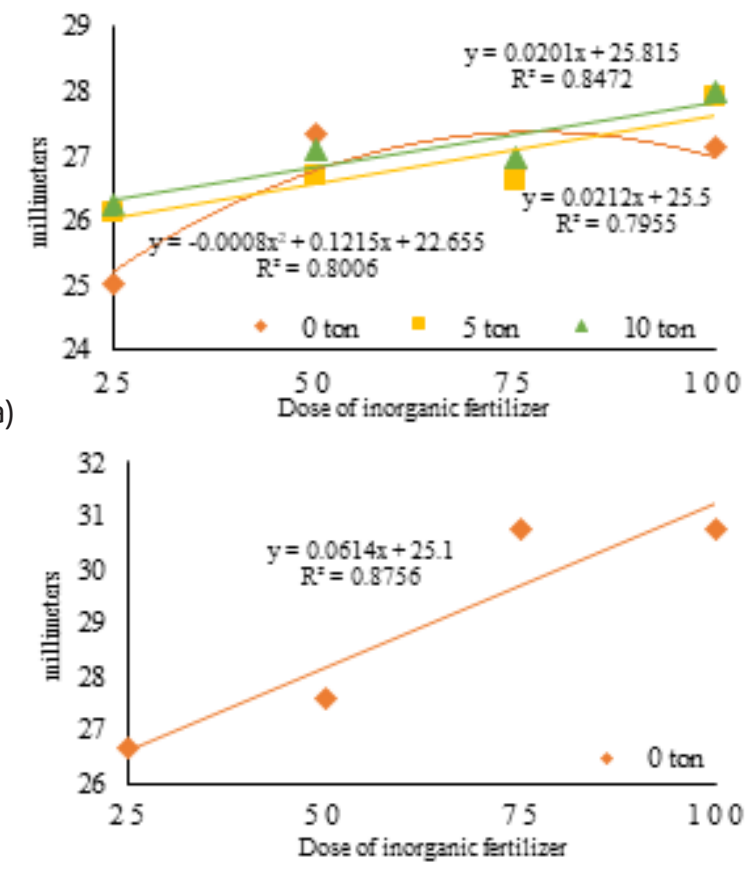

(b)

Figure 3. Curve of the interaction effects of sugarcane variety, filter cake compost and inorganic fertilizer on the stem diameter at 22 WAP: a) PS 881 dan b) PS 862 
Table 5. Interaction effects of sugarcane variety, filter cake compost and inorganic fertilizer on the stem diameter at 22 WAP

\begin{tabular}{|c|c|c|c|c|c|c|}
\hline \multirow{3}{*}{ Inorganic fertilizer } & \multicolumn{3}{|c|}{ PS 881} & \multicolumn{3}{|c|}{ PS 862} \\
\hline & \multicolumn{3}{|c|}{ Filter cake compost } & \multicolumn{3}{|c|}{ Filter cake compost } \\
\hline & 0 ton & 5 ton & 10 ton & 0 ton & 5 ton & 10 ton \\
\hline & \multicolumn{6}{|c|}{ 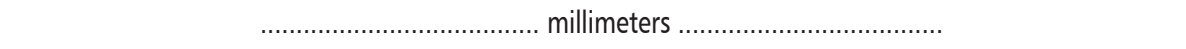 } \\
\hline $25 \%$ & 25.02 & 26.12 & 26.25 & 26.68 & 30.20 & 29.52 \\
\hline $50 \%$ & 27.32 & 26.68 & 27.10 & 27.58 & 29.48 & 30.53 \\
\hline $75 \%$ & 26.81 & 26.59 & 26.97 & 30.74 & 29.67 & 29.10 \\
\hline $100 \%$ & 27.15 & 27.92 & 27.97 & 30.74 & 29.79 & 30.29 \\
\hline Polynomial tests & $0.042 * Q$ & $0.027 * \mathrm{~L}$ & $0.043 * \mathrm{~L}$ & $0.002 * * \mathrm{~L}$ & 0.4746 ns & $0.816 \mathrm{~ns}$ \\
\hline
\end{tabular}

Note: Polynomial orthoghonal tests: ns: not significant; *:significant; **: highly significant; L: linear; Q: quadratic.

According to Table 5 and Figure $3 \mathrm{~b}$, the effect on the stem diameter of PS 862 variety was shown in the absence of filter cake compost. The increasing size of cane diameter was along with an increase in inorganic fertilizer dose.

Effects of filter cake compost and inorganic fertilizer on the sugarcane leaves nutrient content

Based on he analysis on the dry plant weight (Table 6), both sugarcane varieties showed different responses to the application of inorganic fertilizers. This is thought to be due to the morphological differences between the varieties that affect the nutrient absorption process, which are then used for biomass formation. The availability of water and nutrients at 6 months after planting (MAP) was not inhibited, and plant growth focused on the formation of glucose in the stem.

Nitrogen content in the PS 881 leaves was higher than that in PS 862. Conversely, the phosporus content in was higher in PS 862. Meanwhole, both of the filter cake compost and inorganic fertilizer doses have on effects on the $\mathrm{N}$ and $\mathrm{P}$ content in the leaves. The plants did not show a nutrient deficiency response, but they are categorized in the optimum criteria according to Mccray et al. (2006) who mention that the critical point value of nutrients in leaves was $1.80 \% \mathrm{~N}, 0.19 \% \mathrm{P}$, and $0.90 \% \mathrm{~K}$. The rest of the nutrient content was still used in biomass growth and stored in sinks in

Table 6. Plant dry weight and leaves nutrient content at 6 MAP

\begin{tabular}{|c|c|c|c|c|c|c|c|}
\hline \multirow{2}{*}{ Treatment } & \multicolumn{4}{|c|}{ Plant dry weight $(\mathrm{kg})$} & \multicolumn{3}{|c|}{ Leaves nutrient content (\%) } \\
\hline & Root & Stems & Shoots & Leaf & $\mathrm{N}$ & $\mathbf{P}$ & $\mathrm{K}$ \\
\hline \multicolumn{8}{|l|}{ Varieties } \\
\hline PS 881 & $145.94 \mathrm{~b}$ & $1049.1 \mathrm{~b}$ & $30.22 b$ & $165.19 \mathrm{~b}$ & $2.14 \mathrm{a}$ & $0.19 b$ & 1.39 \\
\hline PS 862 & $182.23 \mathrm{a}$ & $1399.1 \mathrm{a}$ & $48.27 \mathrm{a}$ & $218.98 \mathrm{a}$ & $1.77 \mathrm{~b}$ & $0.24 \mathrm{a}$ & 1.45 \\
\hline \multicolumn{8}{|l|}{ Filter cake } \\
\hline 0 ton $\mathrm{ha}^{-1}$ & 168.04 & 1252.9 & 41.39 & 204.69 & 1.94 & $0.21 \mathrm{~b}$ & 1.42 \\
\hline 5 tons ha-1 & 166.18 & 1202.8 & 36.58 & 190.89 & 1.93 & $0.21 \mathrm{~b}$ & 1.36 \\
\hline 10 tons ha ${ }^{-1}$ & 158.05 & 1216.8 & 39.78 & 180.68 & 2.00 & $0.23 a$ & 1.48 \\
\hline \multicolumn{8}{|l|}{ Inorganic fertilizer } \\
\hline $25 \%$ & 130.59 & 1040.3 & 32.77 & 155.82 & 1.84 & 0.22 & 1.47 \\
\hline $50 \%$ & 195.46 & 1302.2 & 47.00 & 209.77 & 1.97 & 0.22 & 1.42 \\
\hline $75 \%$ & 162.61 & 1274.6 & 38.20 & 201.00 & 1.97 & 0.21 & 1.37 \\
\hline $100 \%$ & 167.70 & 1279.4 & 39.01 & 201.75 & 2.04 & 0.22 & 1.42 \\
\hline Polynomial tests & $0.258 \mathrm{~ns}$ & $0.393 \mathrm{~ns}$ & $0.686 \mathrm{~ns}$ & $0.382 \mathrm{~ns}$ & $0.020 * \mathrm{~L}$ & $0.953 \mathrm{~ns}$ & $0.973 \mathrm{~ns}$ \\
\hline
\end{tabular}

Note: Values followed by the same letters within a column are not significantly different at $5 \%$. Polynomial tests for inorganic fertilizer: ns: not significant; *: significant; L: linear; Q: Quadratic; MAP: month after planting. 
Table 7. Interaction effects of sugarcane varieties and filter cake compost on the length and weight of cane stems

\begin{tabular}{lcccc}
\hline \multirow{2}{*}{ Filter cake compost } & \multicolumn{2}{c}{ Length of stems $(\mathrm{cm})$} & \multicolumn{2}{c}{ Stems weight $(\mathrm{kg})$} \\
\cline { 2 - 5 } 0 & PS 881 & PS 862 & PS 881 & $0.60 \mathrm{bx}$ \\
\cline { 2 - 5 } ton ha-1 & $239.25 \mathrm{~d} \mathrm{y}$ & $265.38 \mathrm{bx}$ & $0.53 \mathrm{~d} \mathrm{y}$ & $0.68 \mathrm{ax}$ \\
5 ton ha-1 & $253.66 \mathrm{c} \mathrm{y}$ & $263.61 \mathrm{~b} \mathrm{x}$ & $0.52 \mathrm{~d} \mathrm{y}$ & $0.65 \mathrm{ax}$ \\
10 ton ha- $^{-1}$ & $236.56 \mathrm{~d} \mathrm{y}$ & $271.74 \mathrm{ax}$ & $0.57 \mathrm{cy}$ & \\
\hline
\end{tabular}

Note: Values followed by the same letters within a column are not significantly different at $5 \%$.

the form of glucose. Filter cake compost applied together with $\mathrm{P}$ fertilizer before planting sugarcane could increase the yield of sugarcane per hectare and sugar accumulation (Caione et al., 2015).

\section{Effects of filter cake compost and inorganic fertilizer on} sugarcane yield components

Interaction between filter cake compost and sugarcane varieties significantly affected the length and weight of the stem. Table 7 shows that PS 881 variety is more responsive to filter cake compost in producing stem length, while PS 862 variety is more responsive to filter cake compost in providing stem weights. The number of stems per meter in PS 862 variety was higher than in PS 881 variety. This result because soil organic matter content might have been increased so that it could hold soil moisture, increasing soil water retention. Soil physical properties improvement affected the change in soil aggregate and the increase in organic $\mathrm{C}$ level in the soil. The addition of filter cake compost and zeolite could inmprove aggregate, cation exchange capacity, and microorganisms in the soil (Kumar et al., 2017; Cairo et al., 2017). Sugarcane production was encouraged by the total nutrients absorbed by plants used in the process of photosynthesis to produce a lot of biomass and high levels of glucose formed in the stems. Vasconcelos et al. (2017) reported that the application of filter cake compost significantly enhanced the availability of $\mathrm{P}$ nutrients and plant photosynthetic activity, thereby increasing the stem weight per hectare.

The the application of inorganic fertilizer has a significant effect on the nunber of stems in both PS 881 and PS 862 varieties (Figure 4). Both varieties experienced an increase in the number of stems along with the increasing doses of inorganic fertilizer to the optimum dose. PS 881 showed a more

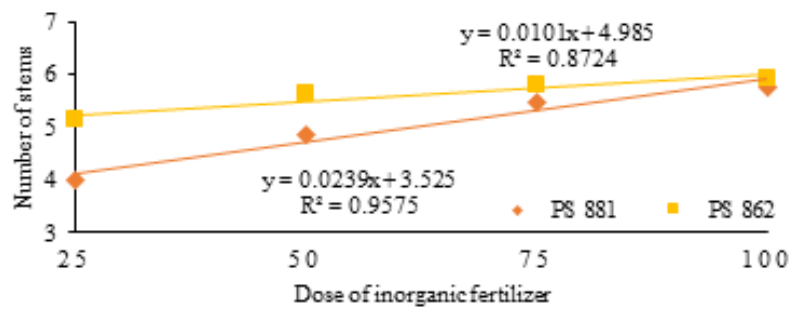

Figure 4. Curve of the interaction effects of sugarcane varieties and inorganic fertilizer on the number of stems

significant increase in the number of stems than PS 862 variety. This phenomenon is presumably due to the influence of plant genetics since that PS 881 variety is an early mature type and PS 862 is a medium mature type. Interaction effects of sugarcane varieties and filter cake compost on the number of stems are presented in Table 8.

Table 8. Interaction effects of sugarcane varieties and inorganic fertilizer on the number of stems

\begin{tabular}{cccccc}
\hline \multirow{2}{*}{ Varieties } & \multicolumn{3}{c}{ Inorganic fertilizer } & \multirow{2}{*}{ Polynomial tests } \\
\cline { 2 - 5 } & $25 \%$ & $50 \%$ & $75 \%$ & $100 \%$ & 0.001 ** L \\
\hline PS 881 & 3.99 & 4.84 & 5.48 & 5.77 & $0.035^{*} \mathrm{~L}$ \\
\hline
\end{tabular}

Note: Polynomial orthoghonal tests: ns: not significant; *:significant; **: highly significant; L: linear; Q: quadratic. 
In the application of filter cake compost at a dose of 0 tons $\mathrm{ha}^{-1}$, the interaction effect of filter cake compost and inorganic fertilizer on the sugarcane yield is illustrated by the quadratic equation $\left(y=-0.0068 x^{2}+1.0442 x+24.74\right)($ Table 9 and Figure 5). The equation of the quadratic curve ilustrates that the optimum dose of inorganic fertilizer is $76.76 \%$ (use the formula: - (b/2.a)). In contrast, the application of filter cake compost at

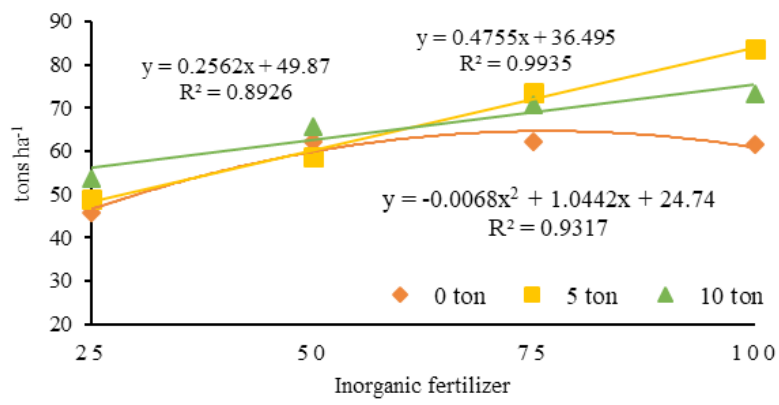

Figure 5. Curve of the interaction effects of filter cake compost and inorganic fertilizer on sugarcane yield

Table 9. Interaction effects of filter cake and inorganic fertilizer on sugarcane yield

\begin{tabular}{lccc}
\hline \multirow{2}{*}{ Inorganic fertilizer } & \multicolumn{3}{c}{ Filter cake compost } \\
\cline { 2 - 4 } & 0 ton ha $^{-1}$ & 5 ton ha & 10 ton ha $^{-1}$ \\
\hline & & $\ldots \ldots \ldots \ldots . .$. & Tonne cane per hectar (TCH) ............. \\
$50 \%$ & 45.75 & 48.98 & 53.62 \\
$75 \%$ & 62.35 & 58.72 & 65.77 \\
$100 \%$ & 62.15 & 73.47 & 70.86 \\
\hline Polynomial tests & 61.67 & 83.69 & 73.27 \\
\hline
\end{tabular}

Note: Polynomial orthoghonal tests: ns: not significant; *:significant; **: highly significant; L: linear; Q: quadratic.

a dose of 5 and 10 tons ha ${ }^{-1}$, the interaction effect is ilustrated by linear curve with $\mathrm{R}$ square of 0.99 and 0.89 . Moreover, the application of filter cake compost on soil could reduce the uusesage of inorganic fertilizers due to the improvement of the soil quality through the availability of nutrients and water content. The most efficient inorganic fertilizer was at a dose of $76.76 \%$ combined with 5 tons ha ${ }^{-1}$ filter cake compost, producing 75.03 tons ha ${ }^{-1}$ of sugarcane. This data consider that per $\mathrm{kg}$ of inorganic fertilizer could produce 0.097 tons cane. However, a combination with 10 tons ha ${ }^{-1}$ filter cake compost produced 72.10 tons $\mathrm{ha}^{-1}$ of sugarcane, and the efficiency of inorganic fertilizer to produce cane declined to 0.093 .

\section{CONCLUSION}

The growth of PS 862 variety was better than that of PS 881 in the plant height, stem diameter, number of stems, number and length of internodes, and yield. PS 881 variety showed a better response than PS 862 in terms of number of internodes and stem length. The optimum dose of inorganic fertilizer was obtained at $75.93 \%$ and $76.76 \%$ to produce a stem diameter of PS 881 variety and sugarcane yield per hectare, respectively. The combination dose of 5 tons ha ${ }^{-1}$ filter cake compost and $76.76 \%$ inorganic fertilizer was more efficient, and it could provide an efficiency of 0.097 tons cane $\mathrm{kg}$ 1. However, it wasn't efficient yet to reduce the use of inorganic fertilizer in producing stem diameter and the yield of both varieties of sugar.

\section{REFERENCES}

Abdurachman, A., Dariah, A., \& Mulyani, A. (2008). upland management strategies and technologies support national food procurement. Jurnal Litbang Pertanian, 27(2), 43-49.

Alvarez-Campos, O., Lang, T. A., Bhadha, J. H., McCray, J. M., Glaz, B., \& Daroub, S. H. (2018). Biochar and mill ash improve yields of sugarcane on a sand soil in Florida. Agriculture, Ecosystems and Environment, 253(17), 122-130.

Arve, L., Torre, S., Olsen, J., \& Tanino, K. (2011). Stomatal Responses to Drought Stress and Air Humidity. In Abiotic Stress in Plant - Mechanisms and Adaptation (pp. 267-280). Croatia: InTech. Retrieved from http://www.intechopen.com/books/abioticstress-in-plants-mechanisms-and- adaptations/stomatalresponses-to-drought-stress-and-air-humidity

Banerjee, K., Puste, A. M., Gunri, S. K., Jana, K., \& Barman, M. (2018). 
Effect of integrated nutrient management on growth, yield, quality and soil health of spring planted sugarcane (Saccharum officinarum) in West Bengal. Indian Journal of Agronomy, 63(4), 41-47.

Budiyanto, G. (2014). Land resource management. Yogyakarta (ID): LP3M UMY

Bot, A., and Benites, J. (2005). The importance of soil organic matter: a key to drought-resistant soil and sustained food production. Food and Agriculture Organization of the United Nations. Rome. Italy Soil Bulletin, page 80.

Caione, G., De Mello Prado, R., Campos, C. N. S., Rosatto Moda, L., De Lima Vasconcelos, R., \& Pizauro Júnior, J. M. (2015). Response of sugarcane in a Red Ultisol to phosphorus rates, phosphorus sources, and filter cake. Scientific World Journal, 15(4), 14-16. https://doi.org/10.1155/2015/405970

Cairo, P. C., de Armas, J. M., Artiles, P. T., Martin, B. D., Carrazana, R. J., \& Lopez, O. R. (2017). Effects of zeolite and organic fertilizers on soil quality and yield of sugarcane. Australian Journal of Crop Science, 11(6), 733-738. https://doi.org/10.21475/ ajcs.17.11.06.p501

Diana, N. E., Supriyadi, \& Djumali. (2016). Growth, productivity, and sugar content of plant cane on several fertilizer pockets. Jurnal Ilmu Pertanian Indonesia, 21(3), 159-166.

Directorate General of Plantations. (2019). Cane production by province in Indonesia year 2015-2019. In the: Last Five Years Data. Indonesia (ID): Ministry of Agriculture. Retrieved from https://www.pertanian.go.id/home/index. php?show=repo\&fileNum=193.

Dotaniya, M. L., Datta, S. C., Biswas, D. R., Dotaniya, C. K., Meena, B. L., Rajendiran, S., Regar, K.L., \& Lata, M. (2016). Use of sugarcane industrial by-products for improving sugarcane productivity and soil health. International Journal of Recycling of Organic Waste in Agriculture, 5(3), 185-194.

Ferreira, T. H. S., Tsunada, M. S., Bassi, D., Araújo, P., Mattiello, L., Guidelli, G. V., Righetto, G.L., Gonçalves, V.R., Lakshmanan, P., \& Menossi, M. (2017). Sugarcane water stress tolerance mechanisms and its implications on developing biotechnology solutions. Frontiers in Plant Science, 8(6), 1-18.

Ghube, N. B., Kadlag, A. D., \& Kamble, B. M. (2017). Impact of different levels of organic and inorganic fertilizers on growth, yield and quality of preseasonal sugarcane ratoon in Inceptisols. Journal of Applied and Natural Science, 9(2), 812-820. https:// doi.org/10.31018/jans.v9i2.1281

Gomez, S. (2013). Recycling agricultural by-products to grow sugarcane on sandy soils in south Florida. Gainesville (U.S.): University of Florida.

Indonesian Center for Agricultural Land Resources. (2015). Land typology information at scale 1:250 000. Indonesia (ID). Retrieved from pertanian.go.id/ind.

Jaili, M. A. Bin, \& Purwono. (2016). Pengurangan dosis pupuk anorganik dengan pemberian kompos blotong pada budi daya tanaman tebu (Saccharum officinarum L.) lahan kering. Buletin Agrohorti, 4(1), 113-121.

Jain, R., Chandra, A., Venugopalan, V. K., \& Solomon, S. (2015). Physiological changes and expression of SOD and P5CS genes in response to water deficit in sugarcane. Sugar Tech, 17(3), 276-282.

Kumar, S., Meena Asstt Professor, R., Singh Jatav, H., Banjara, T.,
Scholar, R., Meena, R., Jinger, D., \& Jatav, H. (2017). Use of pressmud compost for improving crop productivity and soil health. International Journal of Chemical Studies, 5(2), 384-389.

Mastur. (2016). Respon fisiologis tanaman tebu terhadap kekeringan. Buletin Tanaman Tembakau, Serat Dan Minyak Industri, 8(2), 98-111.

Mccray, J. M., Ezenwa, I. V, Rice, R. W., \& Lang, T. A. (2006). Sugarcane Plant Nutrient Diagnosis. In R. Gilbert (Ed.), The Sugarcane (ssagr-128, pp. 1-25). Florida: University of Florida IFAS Extension.

Purwono, Sopandie, D., Harjadi, S. S., \& Mulyanto, B. (2011). Application of filter cake on growth of upland sugarcanes. Jurnal Agronomi Indonesia, 39(2), 79-84.

Rahayu, A., Utami, S. R., \& Rayes, M. L. (2014). Karakteristik dan klasifikasi tanah pada lahan kering dan lahan yang disawahkan di kecamatan perak kabupaten jombang. Jurnal Tanah Dan Sumberdaya Lahan, 1(2), 79-87.

Santos, F., Borém, A., \& Caldas, C. (2015). Sugarcane: Agricultural production, bioenergy and etanol. Elsevier Inc.

Soil Research Institute. (2009). Technical guidance: chemical analysis of soil, plants, water, and fertilizers. (B. Prasetyo, D. Santoso, \& L. R. W, Eds.) (2nd ed.). Bogor (ID): Soil Research Institute.

Shukla, S. K., Singh, P. N., Chauhan, R. S., \& Solomon, S. (2015). Soil physical, chemical and biological changes and long term sustainability in subtropical India through integration of organic and inorganic nutrient sources in sugarcane. Sugar Tech, 17(2), 138-149.

Silva, M.de.A, Jifon, J.L., dos Santos, C.M., Jadoski, C.J., \& da Silva, J.A.G. (2013). Photosynthetic capacity and water use efficiency in sugarcane genotypes subject to water deficit during the early growth phase. Brazilian Archives of Biology and Technology, 56(5),735-748.

Silveira, N. M., Frungillo, L., Marcos, F. C. C., Pelegrino, M. T., Miranda, M. T., Seabra, A. B., Salgado, I., Machado, E.C., \& Ribeiro, R. V. (2016). Exogenous nitric oxide improves sugarcane growth and photosynthesis under water deficit. Planta, 244(1), 181-190.

Supriyadi, S., Diana, N. E., \& Djumali, D. (2018). Pertumbuhan Dan Produksi Tebu (Saccharum Officinarum; Poaceae) Pada Berbagai Paket Pemupukan Di Lahan Kering Berpasir. Berita Biologi, 17(2), 147-156.

Usman, M., Madu, V. U., \& Alkali, G. (2015). The combined use of organic and inorganic fertilizers for improving maize crop productivity in Nigeria. International Journal of Scientific and Research Publications, 5(10), 1-7.

Vasconcelos, R. de L., Almeida, H. J. de, Prado, R. de M., Santos, L. F. J. dos, \& Pizauro Júnior, J. M. (2017). Filter cake in industrial quality and in the physiological and acid phosphatase activities in cane-plant. Industrial Crops and Products, 105(8), 133-141. https://doi.org/10.1016/j.indcrop.2017.04.036

Widiyani, D.P., \& Ariffin. (2017). Test the resistance of two types of sugarcane seedlings (Saccharum officinarum L.) to the level of water stress in the early growth phase of the plant, $5(11)$, 1777-1783.

Zhao, P., Jackson, P.A., Basnayake, J., Liu, J., Chen, X., Zhao, J., Zhao, X., Bai, Y., Yang, L., Zan, F., Yang, K., Xia, H., Qin, W., Zhao, L., Yao, L., Lakshmanan, P., \& Fan, Y. (2017). Genetic variation in sugarcane for leaf functional traits and relationships with cane yield, in environments with varying water stress. Field Crops Research, 213(3), 143-153. 